\title{
Razlike u stavovima o klimatskim promjenama kod menadžera u turističkim smještajnim objektima različitih kategorija
}

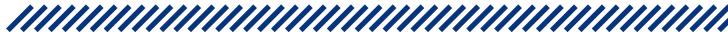 \\ 1 Aleksandar Racz* \\ 2 Dora Smolčić Jurdana \\ ${ }_{1,3}$ Krešimir Rotim* \\ 1 Zdravstveno veleučilište Zagreb, Hrvatska \\ 2 Fakultet za menadžment u turizmu i ugostiteljstvo, \\ Sveučilište u Rijeci, Opatija, Hrvatska \\ 2 Klinika za neurokirurgiju, KBC Sestre milosrdnice, \\ Zagreb, Hrvatska
}

\section{Sažetak}

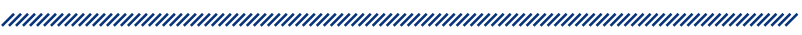

U novije doba, više nego ikad ranije, klimatske su promjene globalnog karaktera i ozbiljno determiniraju razvoj i budućnost turizma u širem obuhvatu turističkih regija i svijetu u cjelini. Klimatske promjene ne predstavljaju samo hipotetski akademski izazov za čovječanstvo, već direktno utječu na sve aspekte ljudskog života, uključujući turizam, koji i sam postaje globalni ekološki problem. U ovom radu fokus interesa bio je usmjeren na istraživanje postojanja povezanosti između kategorije smještajnog objekta izražene zvjezdicama s iskazanim uvjerenjima i stavovima menadžera o klimatskim promjenama i međuutjecaju klimatskih promjena i turizma. $U$ istraživanju je postavljena hipoteza prema kojoj postoje znatne razlike u uvjerenjima i stavovima o klimatskim promjenama i međuutjecaju klimatskih promjena i turističkog smještaja, kao i o klimatskim promjenama kao determinantama oblikovanja turističke ponude između menadžera u različitim kategorijama (dvije do pet zvjezdica) turističkih smještajnih kapaciteta (hoteli, aparthoteli, turistička naselja, kampovi ili marine). Stoga je specifični cilj istraživanja bio utvrditi utječu li kategorija različitih turističkih smještajnih kapaciteta (hoteli, aparthoteli, turistička naselja, kampovi ili marine) na uvjerenja i stavove menadžera o pitanjima klimatskih promjena i međuutjecaju klimatskih promjena i turističkog smještaja, kao i o klimatskim promjenama kao determinantama obli- kovanja turističke ponude. Područje provođenja istraživanja bilo je prostorno određeno na cijelom području Republike Hrvatske i na ukupnoj populaciji svih kategoriziranih turističkih smještajnih objekata, odnosno na 1084 kategorizirana objekta na dan 7. ožujka 2019. prema kategorizaciji koju je provelo Ministarstvo turizma RH. Prikupljanje podataka bilo je provedeno metodom e-anketiranja, pri čemu je od ukupnog broja poslanih anketnih upitnika uredno bilo ispunjeno 283 upitnika, što je predstavljalo odaziv od $26,1 \%$. U skladu s postavljenom hipotezom i ciljem istraživanja dokazano je postojanje znatnih razlika u stavovima menadžera koji upravljaju turističkim smještajnim objektima koji imaju različitu kategorizaciju, odnosno različit broj dodijeljenih zvjezdica, i to po svim tvrdnjama o kojima su izrazili svoj stav, u sve tri komponente stava.

Uvjerenja i stavovi menadžera u smještajnoj turističkoj industriji funkcija su raznih karakteristika smještajnog objekta, pri čemu snažnije proekološke stavove i veću razinu ekološke svijesti o klimatskim promjenama i međuutjecaju klimatskih promjena i turističkog smještaja, kao i o klimatskim promjenama kao determinantama oblikovanja turističke ponude pokazuju menadžeri zaposleni u smještajnim turističkim kategoriziranim objektima $s$ višom kategorijom, odnosno većim brojem zvjezdica.

Ključne riječi: klimatske promjene, uvjerenja, stavovi, turizam, stavovi menadžmenta

Datum primitka: 28.12.2020.

Datum prihvaćanja: 01.04.2021.

https://doi.org/10.24141/1/7/2/5

Adresa za dopisivanje:

Aleksandar Racz

A: Zdravstveno veleučilište Zagreb, Mlinarska 38, Hrvatska

E-pošta: aracz@zvu.hr

T: +385914595722 


\section{Uvod}

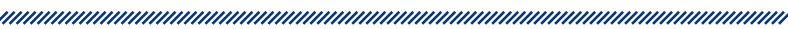

Turizam je jedna od najvećih i najbrže rastućih globalnih djelatnosti, s visokim stopama rasta te ima važnu ulogu u nacionalnim i lokalnim gospodarstvima (Gössling i Hall 2006), kako u Hrvatskoj (Ružić i Demonja 2013) tako i diljem svijeta (Amelung, Nicholls i Viner 2007).

Klimatske promjene imale su znatan utjecaj na putovanja i turizam kroz povijest (Wier 2017), međutim u novije doba, više nego ikad ranije, klimatske su promjene globalnog karaktera i ozbiljno determiniraju razvoj i budućnost turizma u širem obuhvatu turističkih regija i svijetu u cjelini. Klimatske promjene ne predstavljaju samo hipotetski akademski izazov za čovječanstvo, već direktno utječu na sve aspekte ljudskog života, uključujući turizam, koji i sam postaje globalni ekološki problem (Scott, Gössling i Hall 2012).

Ovo istraživanje pošlo je od analize rezultata ranijih istraživanja provedenih kod nas (Petrić i Pranić 2010) ili u svijetu (Deng, Ryan i Moutinho 1992) usmjerenih prema analizi uvjerenja i stavova menadžera u turističkom sektoru o pitanjima zaštite okoliša. lako u pravilu menadžeri pitanja zaštite okoliša i održivog razvoja smatraju važnima, neke odrednice uvjerenja i stavova hotelijera o pitanjima povezanima s klimatskim promjenama ostale su nerazjašnjene. Naime, dosad objavljena istraživanja nisu dala jednoznačne odgovore na pitanja jesu li uvjerenja i stavovi menadžera u turističkim smještajnim objektima o pitanjima zaštite okoliša funkcija pojedinih karakteristika smještajnog objekta, kao što je njegova veličina, kategorija, lokacija, namjena, sezonsko obilježje, duljina poslovanja, vrsta vlasništva, posjedovanje pisanih politika zaštite okoliša i slično. Nekoliko prethodnih istraživanja u svijetu ukazalo je da postoje statistički značajne razlike u stavovima menadžera koji upravljaju objektima različitih karakteristika ili orijentacija (Deng, Ryan i Moutinho 1992), dok nacionalno istraživanje iz 2010. godine nije pokazalo postojanje ikakvih razlika u stavovima turističkih menadžera ovisno o promatranim karakteristikama turističkoga smještajnog objekta (Petrić i Pranić 2010). $\mathrm{U}$ ovom radu zanimalo nas je postoji li povezanost između kategorije smještajnog objekta izražene zvjezdicama $s$ iskazanim uvjerenjima i stavovima menadžera koji vode te smještajne objekte o klimatskim promjenama i međuutjecaju klimatskih promjena i turizma, sve kako bi se dodatno razjasnili različiti rezultati dvaju često citiranih istraživanja. Naime, istraživanje Parka i suradnika (2014) pokazalo je da veličina i kategorija hotela znatno utječu na iskazane stavove menadžera o pitanjima zaštite okoliša i klimatskih promjena, što je bilo u suprotnosti s rezultatima Denga i suradnika iz 1992. godine. Naime, u Parkovu istraživanju pokazano je da su ekološki osvješteniji oni menadžeri koji upravljaju manjim i individualnim objektima neovisno o kategoriji u odnosu na menadžere uključene u veće objekte, kao i objekte koji su uključene u hotelske lance, što je u suprotnosti s rezultatima Dengova istraživanja. lako kategorizacija hotela nužno ne korespondira s njegovom veličinom, uz manji broj iznimaka, hoteli smješteni na jadranskoj obali najviših kategorija u pravilu su razvijeni i izgrađeni na većoj površini te se u ovom radu zadržalo na komparaciji stavova menadžera ovisno o kategoriji hotela koji vode, u skladu s kategorizacijom koju je provelo nadležno Ministarstvo turizma uz poštivanje kategorizacije s brojem zvjezdica od jedan do pet, bez uvođenja i veličine objekta kao moguće varijable, između ostalog i zbog nedostatka preciznih podataka o tom parametru u dostupnim sekundarnim izvorima te izostanku potpunih odgovora ispitanika kroz provedeni anketni upitnik.

\section{Cilj i svrha rada}

$\mathrm{U}$ istraživanju je postavljena hipoteza prema kojoj postoje znatne razlike u uvjerenjima i stavovima o klimatskim promjenama i međuutjecaju klimatskih promjena i turističkog smještaja, kao i o klimatskim promjenama kao determinantama oblikovanja turističke ponude između menadžera u različitim kategorijama (dvije do pet zvjezdica) turističkih smještajnih kapaciteta (hoteli, aparthoteli, turistička naselja, kampovi ili marine).

Stoga je specifični cilj istraživanja bio utvrditi utječu li kategorija (dvije do pet zvjezdica) različitih turističkih smještajnih kapaciteta (hoteli, aparthoteli, turistička naselja, kampovi ili marine) na uvjerenja i stavove menadžera o pitanjima klimatskih promjena i međuutjecaju klimatskih promjena i turističkog smještaja. 


\section{Materijal i metode}

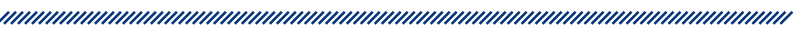

Područje provođenja istraživanja bilo je prostorno određeno na cijelom području Republike Hrvatske i na ukupnoj populaciji svih kategoriziranih turističkih smještajnih objekata po tipu hotela i aparthotela, zatim turističkog naselja i turističkih apartmana, kao i kampova i marina na području Republike Hrvatske obuhvaćenih zadnjim dostupnim Popisom kategoriziranih objekata na dan 7. ožujka 2019. (Ministarstvo turizma Republike Hrvatske 2019). Istraživanje je bilo usmjereno na 1084 objekta, što predstavlja ukupnu populaciju svih navedenih tipova kategoriziranih objekata u Republici Hrvatskoj.

Na području Republike Hrvatske, prema popisu iz 2019. godine, u kategoriji hotela bilo je kategorizirano ukupno 705 objekata s 59386 smještajnih jedinica i ukupno 116009 raspoloživih stalnih kreveta:

- dvije zvjezdice - 53 hotela s ukupno 4352 smještajne jedinice i ukupno 8845 raspoloživih stalnih kreveta

- tri zvjezdice - 305 hotela s ukupno 19420 smještajnih jedinica i s ukupno 38201 raspoloživim stalnim krevetom

- četiri zvjezdice - 308 hotela s ukupno 28223 smještajne jedinice i s ukupno 54779 raspoloživih stalnih kreveta

- pet zvjezdica - 39 hotela s ukupno 5687 smještajnih jedinica i s ukupno 11091 raspoloživim stalnim krevetom.

U kategoriji hotela u Republici Hrvatskoj bio je kategoriziran i 41 objekt od kojih:

- 21 hotel baština (engl. heritage) s ukupno 391 smještajnom jedinicom i ukupno 682 raspoloživa stalna kreveta

- jedan difuzni hotel s ukupno tri smještajne jedinice i s ukupno osam raspoloživih stalnih kreveta

- 15 integralnih hotela s ukupno 300 smještajnih jedinica i s ukupno 653 raspoloživa stalna kreveta

- četiri hotela posebnog standarda s ukupno 1010 smještajnih jedinica i s ukupno 1840 raspoloživih stalnih kreveta.

Na području Republike Hrvatske, prema popisu iz 2019. godine, u kategoriji aparthotela bila su kategorizirana ukupno 22 objekta s ukupno 550 smještajnih jedinica is ukupno 1364 raspoloživa stalna kreveta:
- tri zvjezdice - devet aparthotela s ukupno 171 smještajnom jedinicom i s ukupno 396 raspoloživih stalnih kreveta

- četiri zvjezdice - 13 aparthotela s ukupno 379 smještajnih jedinica i s ukupno 968 raspoloživih stalnih kreveta.

Na području Republike Hrvatske, prema popisu iz 2019. godine, u kategoriji turističkih naselja bilo je kategorizirano ukupno 51 turističko naselje s 9131 smještajnom jedinicom i s ukupno 21917 raspoloživih stalnih kreveta:

- dvije zvjezdice - devet objekata s ukupno 1651 smještajnom jedinicom i s ukupno 4131 raspoloživim stalnim krevetom

- tri zvjezdice - 22 objekata s ukupno 4456 smještajnih jedinica i s ukupno 9741 raspoloživim stalnim krevetom

- četiri zvjezdice - 17 objekata s ukupno 2562 smještajne jedinice i s ukupno 6429 raspoloživih stalnih kreveta

- pet zvjezdica - tri objekta s ukupno 462 smještajne jedinice is ukupno 1616 raspoloživih stalnih kreveta.

Na području Republike Hrvatske, prema popisu iz 2019. godine, u kategoriji turističkih apartmana bilo je kategorizirano ukupno 47 apartmanskih naselja s ukupno 3565 smještajnih jedinica i ukupno 11012 raspoloživih stalnih kreveta kategoriziranih kao:

- dvije zvjezdice - devet objekata s ukupno 1127 smještajnih jedinica i s ukupno 3793 raspoloživa stalna kreveta

- tri zvjezdice - 25 objekata s ukupno 1674 smještajne jedinice is ukupno 4917 raspoloživih stalnih kreveta

- četiri zvjezdice - 13 objekata s ukupno 764 smještajne jedinice i s ukupno 2302 raspoloživa stalna kreveta.

Konačno, na području Republike Hrvatske, prema popisu iz 2019. godine, u kategoriji kampova bila su kategorizirana i ukupno 192 kampa sa 74392 smještajne jedinice/parcele i s ukupno 215337 raspoloživih smještajnih kapaciteta kategorizirana kao:

- dvije zvjezdice - 64 objekta s ukupno 15877 smještajnih jedinica i s ukupno 43626 raspoloživih smještajnih kapaciteta

- tri zvjezdice - 69 objekata s ukupno 26894 smještajne jedinice is ukupno 79111 raspoloživih smještajnih kapaciteta 
- četiri zvjezdice - 56 objekata s ukupno 30703 smještajne jedinice i s ukupno 89846 raspoloživih smještajnih kapaciteta

- pet zvjezdica - tri objekta s ukupno 918 smještajnih jedinica i s ukupno 2754 raspoloživa smještajna kapaciteta.

Sumarno, prema Popisu kategoriziranih objekata iz 2019. godine u kategoriji hotela bilo je kategorizirano ukupno 705 hotela te izdvojeni još i 21 hotel baština, jedan difuzni hotel, 15 integralnih hotela te četiri hotela posebnog standarda, kao i 22 objekata u kategoriji aparthotela, odnosno ukupno 768 smještajnih objekata. U kategoriji turističkih naselja ukupno je bilo kategorizirano 51 turističko naselje te 47 apartmanskih naselja, odnosno ukupno 98 smještajnih objekata. U kategoriji kampova bilo je ukupno 192 kampa te u kategoriji marina 33 marine, odnosno sveukupno 218 smještajnih objekata.

Za utvrđivanje uvjerenja i stavova o klimatskim promjenama i međuutjecaju klimatskih promjena i turističkog smještaja primijenjen je anketni upitnik pripremljen za ovo istraživanje (Racz 2019) kojem je kao polazište poslužio Eurobarometrov upitnik „Special Eurobarometer 409 - Climate change 2013" koji je modificiran u skladu s postavljenim pomoćnim ciljevima i tek djelomično upotrijebljen kao model u manjem segmentu kao dio upitnika za ovo istraživanje. Nadalje, u upitnik su uvrštena i odabrana, ali modificirana pitanja upotrijebljena u prethodnim istraživanjima, međutim ciljano modificirana i usmjerena s obzirom na obuhvaćenu populaciju - menadžere u turističkim smještajnim objektima u Hrvatskoj (Bohdanowicz 2006; Leiserowitz et al. 2015).

Podaci su prikazani tablično i grafički. Priprema podataka izvršena je s pomoću računalnoga tabličnog kalkulatora Microsoft Office Excel. Kolmogorov-Smirnovljevim testom analizirana je raspodjela kontinuiranih numeričkih vrijednosti te su se shodno dobivenim podacima primijenili odgovarajući neparametrijski testovi. Kategorijske i nominalne vrijednosti prikazane su kroz odgovarajuće frekvencije i udjele. Kontinuirane vrijednosti prikazane su kroz medijane i interkvartilne raspone, a razlike između njih analizirane su Kruskal-Wallisovim, odnosno post hoc Mann-Whitneyjevim U-testom.

\section{Rezultati}

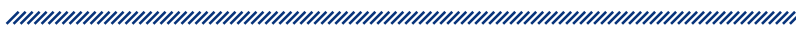

Područje provođenja istraživanja bilo je prostorno određeno na područje Republike Hrvatske na ukupnoj populaciji od 1084 kategorizirana turistička smještajna objekta (hoteli, aparthoteli, turistička naselja, kampovi ili marine). Prikupljanje podataka bilo je provedeno metodom e-anketiranja, pri čemu je od ukupnog broja poslanih anketnih upitnika uredno bilo ispunjeno 283 upitnika, što je predstavljalo odaziv od $26,1 \%$.

Svoja uvjerenja i stavove o klimatskim promjenama i međuutjecaju klimatskih promjena i turističkog smještaja menadžeri su izrazili kroz stupanj slaganja s 36 tvrdnji na Likertovoj 5-stupanjskoj skali, pri čemu su ponuđene tvrdnje pokrivale sve tri komponente stava - kognitivnu, afektivnu i bihevioralnu komponentu. Značajnosti razlike u uvjerenjima i stavovima o klimatskim promjenama i međuutjecaju klimatskih promjena i turističkog smještaja po pojedinim tvrdnjama između menadžera u različitim kategorijama turističkih smještajnih kapaciteta prikazane su tablicama u nastavku uz navođenje df i p-vrijednosti (tablica 1).

Dobiveni rezultati potvrdili su da postoje značajne razlike u stavovima menadžera koji upravljaju različitim kategorijama turističkih smještajnih objekata za svih 36 tvrdnji iz osnovnog upitnika o kojima su izrazili svoj stav, čime je dokazano da se stavovi menadžera koji upravljaju različitim kategorijama turističkih smještajnih objekata o klimatskim promjenama i međuutjecaju klimatskih promjena i turističkog smještaja statistički značajno razlikuju, i to u sve tri komponente stava.

Provedeno je testiranje statističke značajnosti razlika u stavovima ispitanika za kognitivnu, spoznajnu komponentu stava, prikazano tablicom 2.

Dodatno je provedena i post hoc usporedba p-vrijednosti za kognitivnu komponentu stava, što je također prikazano tablicom 3.

Iz provedenih post hoc usporedbi p-vrijednosti može se vidjeti da je u kognitivnoj, spoznajnoj komponenti stava dokazana statistički značajna razlika između stavova menadžera zaposlenih u objektima s dvije zvjezdice u usporedbi sa stavovima menadžera zaposlenih u objektima s četiri ili pet zvjezdica. Razlike postoje i prilikom usporedbi stavova menadžera prema svakoj od kombinacija usporedbi različitih kategorizacija objekata osim kod usporedbe stavova menadžera zaposlenih u objek- 


\section{Tablica 1. Prikaz značajnosti razlike u uvjerenjima i stavovima o klimatskim promjenama i}

međuutjecaju klimatskih promjena i turističkog smještaja između menadžera u različitim kategorijama turističkih smještajnih kapaciteta dobiven primjenom Kruskal-Wallisova testa po pojedinim tvrdnjama

\begin{tabular}{|c|c|c|c|}
\hline & $\begin{array}{l}\text { Kruskal- } \\
\text { Wallis H }\end{array}$ & df & $\mathrm{P}$ \\
\hline Klimatske promjene ozbiljan su problem u svijetu. & 70,922 & 3 & $<0,001$ \\
\hline $\begin{array}{c}\text { Borbom protiv klimatskih promjena i efikasnijom upotrebom energije može se osnažiti ekonomija i turizam te } \\
\text { povećati zapošljavanje. }\end{array}$ & 70,089 & 3 & $<0,001$ \\
\hline $\begin{array}{l}\text { Utjecaj turističkog smještaja na zagađenje okoliša nije zanemariv u usporedbi s dobrobiti koju turizam donosi } \\
\text { lokalnoj zajednici. }\end{array}$ & 43,135 & 3 & $<0,001$ \\
\hline $\begin{array}{c}\text { Klimatske promjene u skoroj budućnosti imat će znatan utjecaj na oblikovanje i razvoj turističke ponude u } \\
\text { Hrvatskoj. }\end{array}$ & 55,507 & 3 & $<0,001$ \\
\hline Globalno zatopljenje uzrokovano je dominantno ljudskim aktivnostima. & 73,546 & 3 & $<0,001$ \\
\hline $\begin{array}{l}\text { Globalno zatopljenje nije dominantno uzrokovano aktivnostima povezanima s prirodnim uzrocima i varijacijama } \\
\text { klime i ovisno je o ljudskom djelovanju. }\end{array}$ & 28,373 & 3 & $<0,001$ \\
\hline $\begin{array}{c}\text { Ukupni utjecaj turizma na globalno zatopljenje i klimatske promjene znatno je veći od utjecaja drugih uslužnih } \\
\text { djelatnosti. }\end{array}$ & 47,302 & 3 & $<0,001$ \\
\hline Klimatske promjene i globalno zatopljenje ugrozit će buduće generacije koje dolaze poslije nas. & 25,279 & 3 & $<0,001$ \\
\hline Klimatsko zatopljenje zapravo se događa. & 38,695 & 3 & $<0,001$ \\
\hline Turistička djelatnost velik je potrošač energije, znatan korisnik prostora i ostalih resursa. & 76,096 & 3 & $<0,001$ \\
\hline Turistička djelatnost ovisi o očuvanom okolišu kao resursu, ali, paradoksalno, istodobno negativno utječe na okoliš. & 77,673 & 3 & $<0,001$ \\
\hline Zaštita okoliša u smislu smanjivanja globalnog zatopljenja ključna je za održivi razvoj turizma. & 87,556 & 3 & $<0,001$ \\
\hline $\begin{array}{l}\text { Važno je da Vlada na nacionalnoj razini postavi nacionalne ciljeve za povećanje upotrebe obnovljive energije, kao } \\
\text { što je energija vjetra ili solarna energija. }\end{array}$ & 31,697 & 3 & $<0,001$ \\
\hline Primjena načela održivog razvoja u poslovnoj praksi važan je izvor konkurentske prednosti. & 73,434 & 3 & $<0,001$ \\
\hline Znanstvenici imaju jasan odgovor čime je uzrokovano globalno zatopljenje. & 32,241 & 3 & $<0,001$ \\
\hline $\begin{array}{c}\text { Važno da Vlada na nacionalnoj razini kontinuirano osigurava materijalne potpore programima poboljšanje } \\
\text { energetske učinkovitosti. }\end{array}$ & 22,877 & 3 & $<0,001$ \\
\hline Klimatske promjene već danas znatno definiraju i mijenjanju razvoj turističke ponude u svijetu. & 63,055 & 3 & $<0,001$ \\
\hline Klimatske promjene mogle bi ugroziti mene osobno ili moju obitelj. & 17,751 & 3 & $<0,001$ \\
\hline Klimatske promjene izazivaju nesigurnosti glede uspješnog poslovanja u turizmu. & 21,186 & 3 & $<0,001$ \\
\hline Pojedinac nije nemoćan i bespomoćan u borbi protiv klimatskih promjena. & 65,846 & 3 & $<0,001$ \\
\hline Zagađivanja okoliša nije neizbježna posljedica razvoja. & 76,311 & 3 & $<0,001$ \\
\hline $\begin{array}{l}\text { Promjene u okolišu poput porasta prosječne temperature ili porasta razine mora nisu toliko spore i zbog toga treba } \\
\text { biti uznemiren. }\end{array}$ & 45,837 & 3 & $<0,001$ \\
\hline $\begin{array}{c}\text { U proteklih šest mjeseci trudio sam se osobno podržavati i sudjelovati u akcijama usmjerenima smanjivanju } \\
\text { klimatskih promjena. }\end{array}$ & 69,528 & 3 & $<0,001$ \\
\hline $\begin{array}{c}\text { Prilikom nabave novog vozila niska potrošnja goriva i ekološki parametri važniji su mi od cijene vozila prilikom } \\
\text { donošenja odluke o izboru. }\end{array}$ & 50,564 & 3 & $<0,001$ \\
\hline $\begin{array}{l}\text { Prilikom izgradnje novog ili adaptacije postojećeg objekata važno mi je voditi se konceptom niskoenergetske } \\
\text { potrošnje, bez obzira na to što su početna ulaganja veća nego kod klasične gradnje. }\end{array}$ & 65,633 & 3 & $<0,001$ \\
\hline $\begin{array}{l}\text { Prilikom odabira dobavljača energije, ako bih imao mogućnost izbora, odabrao bih onoga tko nudi veći udio } \\
\text { energije iz obnovljivih izvora, neovisno o većoj cijeni. }\end{array}$ & 56,503 & 3 & $<0,001$ \\
\hline $\begin{array}{l}\text { Pokušavam smanjiti količinu ambalažnog otpada kupovinom proizvoda s minimalnom ili ambalažom koja se } \\
\text { reciklira. }\end{array}$ & 72,006 & 3 & $<0,001$ \\
\hline $\begin{array}{l}\text { Trudim se kupovati lokalne prehrambene proizvode lokalnih proizvođača iako na tržištu mogu naći i jeftinije } \\
\text { proizvode udaljenijih proizvođača ili iz uvoza. }\end{array}$ & 51,245 & 3 & $<0,001$ \\
\hline $\begin{array}{l}\text { Prilikom kupnje novoga elektroničkog ili kućanskog aparata, npr. bijele tehnike ili elektroničkih uređaja, odabirem } \\
\text { ih prvenstveno prema kriterijima energetske učinkovitosti i najpovoljnijeg odabira energetskog razreda. }\end{array}$ & 77,236 & 3 & $<0,001$ \\
\hline Svakodnevno nastojim smanjiti potrošnju vode i energije. & 26,973 & 3 & $<0,001$ \\
\hline Pri pomisli na klimatske promjene osjećam: strah. & 13,067 & 3 & 0,004 \\
\hline Pri pomisli na klimatske promjene osjećam: ljutnju. & 98,684 & 3 & $<0,001$ \\
\hline Pri pomisli na klimatske promjene ne osjećam: bespomoćnost. & 67,003 & 3 & $<0,001$ \\
\hline Pri pomisli na klimatske promjene ne osjećam: ravnodušnost. & 25,763 & 3 & $<0,001$ \\
\hline Pri pomisli na klimatske promjene osjećam: uznemirenost. & 24,192 & 3 & $<0,001$ \\
\hline Pri pomisli na klimatske promjene osjećam: osobnu krivnju. & 44,059 & 3 & $<0,001$ \\
\hline
\end{tabular}




\begin{tabular}{|c|c|c|c|c|c|c|c|c|c|c|}
\hline & & \multicolumn{8}{|c|}{ Kognitivna komponenta } & \multirow[b]{2}{*}{ P } \\
\hline & & $\mathrm{N}$ & SV & $\mathrm{SD}$ & Minimum & Maksimum & $\begin{array}{l}\text { Percentil } \\
25 \\
\end{array}$ & Medijan & $\begin{array}{c}\text { Percentil } \\
75 \\
\end{array}$ & \\
\hline \multirow{4}{*}{$\begin{array}{c}\text { Kategorizacija } \\
\text { objekta }\end{array}$} & 2 zvjezdice & 39 & 51,65 & 16,95 & 24,24 & 90,91 & 38,64 & 46,97 & 59,85 & \multirow{4}{*}{$<0,001$} \\
\hline & 3 zvjezdice & 111 & 57,94 & 18,84 & 22,73 & 95,45 & 40,15 & 59,09 & 73,48 & \\
\hline & 4 zvjezdice & 112 & 76,21 & 8,54 & 52,27 & 91,67 & 70,83 & 78,03 & 81,82 & \\
\hline & 5 zvjezdica & 21 & 77,42 & 14,72 & 19,70 & 93,18 & 75,00 & 80,30 & 84,09 & \\
\hline
\end{tabular}

tima s četiri zvjezdice u usporedbi s onima zaposlenima u objektima s pet zvjezdica, kao i između menadžera zaposlenih u objektima s dvije zvjezdice u usporedbi sa stavovima onih zaposlenih u objektima s tri zvjezdice, što je i razumljivo s obzirom na to da su razlike između tih dviju kategorija relativno manje nego razlike između ostalih ispitivanih kategorija u rasponu od više od jedne zvjezdice.

\begin{tabular}{|c|c|}
\hline \multicolumn{2}{|c|}{$\begin{array}{l}\text { Tablica 3. Post hoc usporedbe p-vrijednosti } \\
\text { za kognitivnu, spoznajnu komponentu } \\
\text { stava }\end{array}$} \\
\hline $\begin{array}{l}\text { Post hoc usporedbe } \\
\text { p-vrijednosti }\end{array}$ & $\begin{array}{l}\text { Kognitivna } \\
\text { komponenta }\end{array}$ \\
\hline 2 vs 3 & 0,062 \\
\hline 2 vs 4 & $<0,001$ \\
\hline 2 vs 5 & $<0,001$ \\
\hline 3 vs 4 & $<0,001$ \\
\hline 3 vs 5 & $<0,001$ \\
\hline 4 vs 5 & 0,165 \\
\hline
\end{tabular}

Nadalje, provedeno je testiranje statističke značajnosti razlika u stavovima ispitanika za afektivnu, emocionalnu komponentu stava, a rezultati su prikazani tablicom 4.
Dodatno je provedena i post hoc usporedba p-vrijednosti za afektivnu komponentu stava, što je također prikazano tablicom 5.

$\begin{gathered}\text { Tablica } 5 \text {. Post hoc usporedbe p-vrijednosti } \\ \text { za afektivnu, emocionalnu komponentu } \\ \text { stava }\end{gathered}$
$\begin{gathered}\text { Post hoc usporedbe } \\ \text { p-vrijednosti }\end{gathered}$
$\begin{gathered}\text { Afektivna } \\ \text { komponenta }\end{gathered}$
2 vs 3
2 vs 5
3 vs 4
3 vs 5
4 vs 5

Iz provedenih post hoc usporedbi p-vrijednosti prikazanih tablicom 5 može se vidjeti da je u afektivnoj ili emocionalnoj komponenti stava dokazana statistički značajna razlika u stavovima menadžera zaposlenih u objektima s dvije zvjezdice u usporedbi sa stavovima menadžera zaposlenih u objektima s tri, četiri ili pet zvjezdica. Razlike postoje i prilikom usporedbe stavova menadžera kod svake od kombinacija razina kategori-

\begin{tabular}{|c|c|c|c|c|c|c|c|c|c|c|}
\hline & & \multicolumn{8}{|c|}{ Afektivna komponenta } & \multirow[b]{2}{*}{$\mathrm{P}$} \\
\hline & & $\mathrm{N}$ & SV & SD & Minimum & Maksimum & $\begin{array}{l}\text { Percentil } \\
25\end{array}$ & Medijan & \begin{tabular}{|l} 
Percentil \\
75
\end{tabular} & \\
\hline \multirow{4}{*}{$\begin{array}{c}\text { Kategorizacija } \\
\text { objekta }\end{array}$} & 2 zvjezdice & 39 & 33,05 & 18,06 & 11,11 & 69,44 & 16,67 & 25,00 & 52,78 & \multirow{4}{*}{$<0,001$} \\
\hline & 3 zvjezdice & 111 & 48,55 & 21,09 & 8,33 & 83,33 & 27,78 & 52,78 & 66,67 & \\
\hline & 4 zvjezdice & 112 & 63,91 & 12,32 & 27,78 & 86,11 & 58,33 & 66,67 & 72,22 & \\
\hline & 5 zvjezdica & 21 & 64,42 & 12,19 & 30,56 & 83,33 & 63,89 & 66,67 & 69,44 & \\
\hline
\end{tabular}




\begin{tabular}{|c|c|c|c|c|c|c|c|c|c|c|}
\hline & & \multicolumn{8}{|c|}{ Konativna komponenta } & \multirow[b]{2}{*}{$\mathrm{P}$} \\
\hline & & $\mathrm{N}$ & SV & SD & Minimum & Maksimum & $\begin{array}{l}\text { Percentil } \\
25 \\
\end{array}$ & Medijan & $\begin{array}{c}\text { Percentil } \\
75 \\
\end{array}$ & \\
\hline \multirow{4}{*}{$\begin{array}{c}\text { Kategorizacija } \\
\text { objekta }\end{array}$} & 2 zvjezdice & 39 & 56,89 & 16,46 & 33,33 & 89,58 & 43,75 & 50,00 & 70,83 & \multirow{4}{*}{$<0,001$} \\
\hline & 3 zvjezdice & 111 & 67,02 & 18,15 & 33,33 & 100,00 & 50,00 & 70,83 & 83,33 & \\
\hline & 4 zvjezdice & 112 & 83,20 & 11,99 & 37,50 & 100,00 & 77,08 & 85,42 & 91,67 & \\
\hline & 5 zvjezdica & 21 & 87,40 & 12,08 & 56,25 & 100,00 & 81,25 & 87,50 & 100,00 & \\
\hline
\end{tabular}

zacije objekata osim kod usporedbe stavova menadžera zaposlenih u objektima s četiri zvjezdice u usporedbi s onima zaposlenima u objektima s pet zvjezdica, što je i razumljivo s obzirom na to da su razlike između tih dviju kategorija relativno manje nego između ostalih ispitivanih kategorija. Rezultati pokazuju i da su kod afektivne komponente stavova ekološki najsvjesniji menadžeri koji su zaposleni u objektima s četiri i pet zvjezdica, odnosno da se može zaključiti da što je viša kategorija objekta, utvrđuje se i veća razina razvijenosti ekološke svijesti u segmentu afektivne komponente.

Konačno, provedeno je testiranje statističke značajnosti razlika u stavovima ispitanika za konativnu, ponašajnu komponentu stava, što je prikazano tablicom 6.

Dodatno je provedena i post hoc usporedba p-vrijednosti za konativnu komponentu stava, što je također prikazano tablicom 7.

\begin{tabular}{|c|c|}
\hline $\begin{array}{c}\text { Tablica 7. Post hoc usporedbe p-vrijednosti } \\
\text { za konativnu, ponašajnu komponentu stava }\end{array}$ \\
\begin{tabular}{c|c} 
Post hoc usporedbe & Konativna \\
p-vrijednosti & komponenta \\
\hline 2 vs 3 & 0,002 \\
2 vs 4 & $<0,001$ \\
2 vs 5 & $<0,001$ \\
3 vs 4 & $<0,001$ \\
3 vs 5 & $<0,001$ \\
4 vs 5 & 0,108 \\
\hline
\end{tabular}
\end{tabular}

Iz provedenih post hoc usporedbi p-vrijednosti može se vidjeti da je u konativnoj, ponašajnoj komponenti stava dokazana statistički značajna razlika između stavova menadžera zaposlenih u turističkim smještajnim objektima s dvije zvjezdice kada se usporede sa stavovima menadžera zaposlenih u turističkim smještajnim objek- tima s tri, četiri ili pet zvjezdica. Razlike postoje i prilikom usporedbi uvjerenja i stavova menadžera zaposlenih u različito kategoriziranim objektima, osim kod usporedbe uvjerenja i stavova menadžera zaposlenih u objektima s četiri zvjezdice u usporedbi s uvjerenjima i stavovima menadžera zaposlenih u turističkim smještajnim objektima s pet zvjezdica, što je i razumljivo s obzirom na to da su razlike između te dvije kategorije relativno manje nego između ostalih kategorija. Podaci pokazuju i da su kod konativne komponente stavova ekološki najsvjesniji oni menadžeri koji su zaposleni u turističkim smještajnim objektima s pet zvjezdica, odnosno da se može zaključiti da što je viša kategorija turističkim smještajnim objekta, utvrđuje se i veća razina razvijenosti ekološke svijesti u segmentu konativne komponente.

\section{Diskusija}

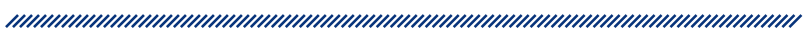

Rezultati ovog rada mogu se sagledati i kroz prizmu rezultata ranijih radova koji su pokazali da su veličina $\mathrm{i}$ kategorija hotela važan čimbenik pri uspješnoj primjeni održivog ponašanja u praksi (Dalton, Lockington i Baldock 2007; Nichols i Kang 2012; Chan 2013; Su, Hall i Ozanne 2013; Ali et al. 2014), pri čemu veći, više kategorizirani hoteli efikasnije i dugoročnije ulažu u „zelene" inicijative (McNamarra i Gibson 2008; Mackenzie i Peters 2014). Uočeno se povezuje s većom količinom raspoloživih sredstva, strogom i razvijenom poslovnom kulturom i pripadnošću međunarodnim turističkim lancima u kojima je ekološka održivost poslovanja uključena u temeljne vrijednosti. 
Nadalje, Kirk (1998) je pretpostavio da bi, s obzirom na snažnu vezu između veličine utjecaja na okoliš smještajnog objekta, kao i njegove veličine i okupiranosti prostora i njegove kategorije, ispitanici povezani s hotelima visoke kategorije (četiri i pet zvjezdica) trebali jednako tako iskazivati jače osviještene stavove o zaštiti okoliša. Rezultati ovog istraživanja potvrdili su isto ono što je Kirk potvrdio u svojem istraživanju.

Rezultati ovog rada pružaju niz uvida koji mogu imati važnost za razvoj održivih praksi u turizmu i posebice hotelskoj djelatnosti općenito, s obzirom na to da pružaju doprinos razumijevanju stavova ključnih donositelja odluka i mogu dati osnove za predviđanje njihova ponašanja u vezi s primjenom mjera zaštite okoliša od negativnog utjecaja turističke djelatnosti koji je nedvojben. Navedeno je važno jer nije vjerojatno da će razvoj turizma koji dosljedno zanemaruje pitanja okoliša ostati dugoročno održiv (Pigram 1990). Održivi turizam trebao bi optimalno iskoristiti resurse okoliša koji predstavljaju ključni element u razvoju turizma, održavanju bitnih ekoloških procesa i pomažu očuvanju prirodne baštine i biološke raznolikosti (UNWTO 2005).

Najvažniji zadatak ekološki opredijeljenih smještajnih turističkih subjekata, posebice onih koji imaju implementirane postavke održivog razvoja, jest proces uvođenja i razvoja ekološke kulture. Takav proces uključuje ključnu ulogu ekološki osviještenog menadžmenta koji demonstrira i implementira predanost odozgo prema dolje, potiče široku komunikaciju i konzultacije, u praksi naglašava važnost razvijanja i primjene internog programa za izgradnju ekološke svijesti u poslovnoj kulturi osoblja, intenzivno radi na podizanju ekološke svijesti kako kod osoblja tako i kod gostiju, izgrađuje predanost, pruža podršku, nagrade i priznanje za poduzete praktične korake te slavi svaki napredak i uspjeh u promicanju održivog razvoja i društveno i ekološki odgovornog ponašanja.

Ovaj rad predstavlja poticaj daljnjem istraživanju uvjerenja i stavova svih dionika uključenih u turističku djelatnost s obzirom na to da, u skladu s trojnom strukturom stavova implementacija dobre prakse, ovisi o prethodno usvojenim stavovima koji se mogu razvijati, mijenjati i graditi u cilju očuvanja i opstanka ljudske civilizacije koja je antropogeno izazvanim klimatskim promjenama dovedena do ruba opstojnosti, posebice u slučaju ostvarenja scenarija od povećanja globalne temperature za dva stupnja i više do kraja ovog stoljeća.

\section{Zaključak}

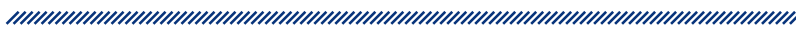

Klimatske promjene ne predstavljaju samo jedinstveni izazov za čovječanstvo, već utječu na sve aspekte ljudskog života, uključujući turizam, ali i postaju globalni ekološki problem. Također, s obzirom na to da je klima jedan od važnijih pokretača turizma, u budućnosti će imati još važniju ulogu u definiranju privlačnosti pojedine destinacije, kao i odlučivanju turista o izboru destinacije. Osim toga, klimatske promjene mijenjaju uvjete u kojima već sada posluju, a u kojima će u neposrednoj budućnosti poslovati turističke destinacije te će klimatske promjene znatno utjecati na upravljanje turističkim tokovima i imovinom te na uspješno poslovanje turističkih poduzeća.

U skladu s postavljenom hipotezom i ciljem istraživanja, dokazano je postojanje znatnih razlika u stavovima menadžera koji upravljaju turističkim smještajnim objektima koji imaju različitu kategorizaciju, odnosno različit broj dodijeljenih zvjezdica, i to po svim tvrdnjama o kojima su izrazili svoj stav, u sve tri komponente stava.

Uvjerenja i stavovi menadžera u smještajnoj turističkoj industriji funkcija su raznih karakteristika smještajnog objekta, pri čemu snažnije proekološke stavove i veću razinu ekološke svijesti o klimatskim promjenama i međuutjecaju klimatskih promjena i turističkog smještaja, kao i o klimatskim promjenama kao determinantama oblikovanja turističke ponude pokazuju menadžeri zaposleni u smještajnim turističkim kategoriziranim objektima s višom kategorijom, odnosno većim brojem zvjezdica. 


\section{Referencije}

1. Ali Y, et al. Energy and environmental performance: Exploratory indicators in the accommodation sector in Jordan. International Journal of Applied Engineering Research. 2014; 9: 4467-4480.

2. Amelung B, Nicholls S, Viner D. Implications of global climate change for tourism flows and seasonality. Journal of Travel Research. 2007; 45(3): 285-296. http://journals. sagepub.com/doi/abs/10.1177/0047287506295937

3. Bohdanowicz P. European hoteliers' environmental attitudes: Greening the business. Cornell hotel and restaurant administration quarterly. 2005; 46(2): 188-204.

4. Chan ESW. Managing green marketing: Hong Kong hotel managers' perspective. International Journal of Hospitality Management. 2013; 34: 442-461. https://doi. org/10.1016/j.ijhm.2012.12.007

5. Dalton GJ, Lockington DA, Baldock TE. A survey of tourist operator attitudes to renewable energy supply in Queensland, Australia. Renewable Energy. 2007; 32(4): 567-586. https://doi.org/10.1016/j.renene.2006.02.006

6. Deng SL, Ryan C, Moutinho L. Canadian hoteliers and their attitudes towards environmental issues. International Journal of Hospitality Management. 1992; 11(3): 225-237. https://doi.org/10.1016/0278-4319(92)90020-V

7. Gössling S, Hall CM. Tourism and global environmental change: Ecological, social, economic and political interrelationships. Vol. 4. Taylor \& Francis, 2006. https:// doi.org/10.1111/j.1745-5871.2007.00438.x

8. Leiserowitz AA. American risk perceptions: Is climate change dangerous?. Risk Analysis: An International Journal. 2005; 25(6): 1433-1442. https://onlinelibrary.wiley. com/doi/abs/10.1111/j.1540-6261.2005.00690.x

9. Leiserowitz A. International public opinion, perception, and understanding of global climate change. Human development report 2007/2008. 2007; 31: 1-40. https:// core.ac.uk/download/pdf/6248846.pdf

10. Mackenzie M, Peters M. Hospitality managers' perception of corporate social responsibility: An explorative study. Asia Pacific Journal of Tourism Research. 2014 19(3): 257-272. https://doi.org/10.1080/10941665.2012.742915

11. McNamara KE, Gibson C. Environmental sustainability in practice? A macro-scale profile of tourist accommodation facilities in Australia's coastal zone. Journal of Sustainable Tourism. 2008; 16(1): 85-100. https://doi. org/10.2167/jost621.0
12. Nicholls S, Kang S. Going green: the adoption of environmental initiatives in Michigan's lodging sector. Journal of Sustainable Tourism. 2012; 20(7): 953-974. https:// doi.org/10.1080/09669582.2011.645577

13. Park J, Kim HJ, McCleary KW. The impact of top management's environmental attitudes on hotel companies' environmental management. Journal of Hospitality \& Tourism Research. 2014; 38(1): 95-115. https://journals. sagepub.com/doi/abs/10.1177/1096348012452666

14. Petrić L, Pranić Lj. Ekološka svijest u hrvatskoj smještajnoj industriji. Acta turistica nova. 2010; 4(1): 5-21. http:// hrcak.srce.hr/61460

15. Pigram JJ. Sustainable tourism-policy considerations. Journal of Tourism Studies. 1990; 1(2): 2-9. https://www. cabdirect.org/cabdirect/abstract/19911896686

16. Racz A. Klimatske promjene kao determinante oblikovanja turističke ponude: stavovi menadžmenta. Diss. University of Rijeka. Faculty of Tourism and Hospitality Management, 2019.

17. Ružić P, Demonja D. Prirodna i antropogena osnova turizma Hrvatske. Sociologija i prostor: časopis za istraživanje prostornoga i sociokulturnog razvoja. 2013, 51(1) (195): 45-65. http://hrcak.srce.hr/index. php?show=clanak\&id_clanak_jezik=150104

18. Scott D, Gössling S, Hall CM. International tourism and climate change. Wiley Interdisciplinary Reviews: Climate Change. 2012; 3(3): 213-232. https://doi.org/10.1002/ wcc. 165

19. Su YP, Hall CM, Ozanne L. Hospitality industry responses to climate change: A benchmark study of Taiwanese tourist hotels. Asia Pacific Journal of Tourism Research. 2013; 18(1-2): 92-107. https://doi.org/10.1080/10941665 .2012 .688513

20. UNWTO. Tourism and Climate change. Responding to Global Challenges. Madrid: World Tourism Organization and the United Nations Environment Programme, 2008. https:// sdt.unwto.org/sites/all/files/docpdf/climate2008.pdf

21. Weir B. Climate change and tourism - Are we forgetting lessons from the past? Journal of Hospitality and Tourism Management. 2017; 32: 108-114. https://doi. org/10.1016/j.jhtm.2017.05.002 


\section{DIFFERENCES IN ATTITUDES ABOUT CLIMATE CHANGE AMONG MANAGERS IN TOURIST ACCOMMODATION FACILITIES OF DIFFERENT CATEGORIES}

1 Aleksandar Racz

2 Dora Smolčić Jurdana

${ }^{1,3}$ Krešimir Rotim

1 University of Applied Health Sciences, Zagreb, Croatia

2 Faculty of Tourism and Hospitality Management, University of Rijeka, Opatija, Croatia

2 Department of Neurosurgery, Sestre milosrdnice University Hospital Center, Zagreb, Croatia

\section{Abstract

In recent times, more than ever before, climate change has become global and it seriously determines the development and future of tourism in the wider range of tourist regions and the world as a whole. Climate change is not only a hypothetical academic challenge for humanity but directly affects all aspects of human life, including tourism, which itself is becoming a global environmental problem. This paper focuses on exploring the existence of a correlation between the category of accommodation facility categorized by a star marking system with expressed beliefs and attitudes of managers about climate change and the interinfluence between climate change and tourism. The research hypothesized that there are significant differences in beliefs and attitudes about climate change and the interinfluence between climate change and tourist accommodation, as well as about climate changes as determinants in shaping the tourist offer, between managers in different categories (2-5 stars) of tourist accommodation facilities (hotels, apartholtels, resorts, camps or marinas). Therefore, the specific objective of the research was to determine whether the categories of different tourist accommodation capacities (hotels, aparthotels, resorts, camps or marinas) influence managers' beliefs and attitudes towards climate change and the interinfluence between climate change and tourist accommodation, as well as climate change as determinant in shaping the tourist offers. The research encompassed the entire territory of the Republic of Croatia and all categorized tourist accommodation facilities, i.e., all 1084 facilities which were categorized in accordance with the categorization carried out by the Ministry of Tourism on the date of 7 March 2019. Data collection was carried out using the e-survey method, whereby out of the total number of sent survey questionnaires, 283 questionnaires were duly completed, which represented a response of $26.1 \%$.

In accordance with the hypothesis and the goal of the research, the existence of significant differences in the attitudes of managers of tourist accommodation facilities with different categorization or different number of awarded stars has been proven in all three components of the attitude items. Beliefs and attitudes of managers in the accommodation tourism industry are a function of various characteristics of the accommodation facility, with stronger pro-environmental attitudes and a higher level of environmental awareness about climate change and interinfluence between climate change and tourism accommodation, as well as climate change as determinants of tourism offer, are expressed by managers of tourist accommodation facilities of a higher category or with a higher number of stars.

Keywords: climate change, attitudes, beliefs, tourism, management attitudes 